Kansas State University Libraries

New Prairie Press

\title{
LONG-TERM TILLAGE EFFECTS ON CONTINUOUS CORN YIELDS
}

\author{
T. B. Bailey \\ J. B. Swan \\ R L. Higgs \\ W. H. Paulson
}

See next page for additional authors

Follow this and additional works at: https://newprairiepress.org/agstatconference

Part of the Agriculture Commons, and the Applied Statistics Commons

\section{(c) (1) $\Theta$}

This work is licensed under a Creative Commons Attribution-Noncommercial-No Derivative Works 4.0 License.

\section{Recommended Citation}

Bailey, T. B.; Swan, J. B.; Higgs, R L.; and Paulson, W. H. (1996). "LONG-TERM TILLAGE EFFECTS ON CONTINUOUS CORN YIELDS," Conference on Applied Statistics in Agriculture. https://doi.org/10.4148/ 2475-7772.1315

This is brought to you for free and open access by the Conferences at New Prairie Press. It has been accepted for inclusion in Conference on Applied Statistics in Agriculture by an authorized administrator of New Prairie Press. For more information, please contact cads@k-state.edu. 
Author Information

T. B. Bailey, J. B. Swan, R L. Higgs, and W. H. Paulson

This is available at New Prairie Press: https://newprairiepress.org/agstatconference/1996/proceedings/3 


\section{LONG-TERM TILLAGE EFFECTS ON CONTINUOUS CORN YIELDS}

T.B. Bailey, Statistics Dep. Agric. and Home Econ. Exp. Stn. and Dep. of Statistics, Iowa State Univ.; J.B. Swan, Dep. of Agronomy, Iowa state Univ., Ames, IA 50011 formerly Dep. of Soil Science, Univ. of Minnesota, St. Paul, MN 55108; R.L. Higgs, Dep. of Agric. Sciences, Univ. of Wisconsin-Platteville, Platteville, WI 53818; W.H. Paulson, Univ. of Wisconsin Exp. Stn., Madison, WI 53706 .

\section{ABSTRACT}

Long-term comparisons of alternative tillage systems are needed to evaluate their effect on corn (Zea mays $L_{.}$) yield under the variable temperature and rainfall conditions of the corn Belt. our objective was to evaluate long-term effects of alternative tillage systems on corn growth and yield on low organic matter silt loam soils. The effect of no-tillage (NT), chisel plow (CP), and moldboard plow (MP) treatments on plant density and grain yield was measured from 1981 through 1990 on Palsgrove and Rozetta silt loam (fine-silty, mixed mesic Typic Hapludalfs) soils. Tillage treatments were randomly allocated to plots in 1981 and treatments were applied in subsequent years without rerandomization. Therefore, measurements over years on the same plot were treated as repeated measures. Grain yields for all tillage treatments were primarily affected by water stress, which varied with yearly weather conditions. Grain yield decreased approximately $0.3 \mathrm{Mg} \mathrm{ha}^{-1}$ per $\mathrm{cm}$ weighted water stress (WWS) for WWS $>8 \mathrm{~cm}$. No statistically significant yield differences among tillage treatments, when averaged over the 10-year period covered by the experiment, were detected. A combined analysis indicated that yield differences among tillage treatments did not depend on whether water stress or non-stress conditions occurred. Over half the variation in yearly differences in grain yield between tilled and NT treatments was explained by differences in plant density. Years were classified as stress or non-stress years on the basis of observed water stress and yearly weather factors. Variability among years was partitioned into variability among years within stress years and non-stress years. The difference in mean yields between ending (1989-90) and beginning (1981-82) years were used to investigate cumulative effects of tillage treatments.

\section{INTRODUCTION}

Tillage can affect corn (Zea mays $L_{.}$) growth and yield through effects on plant density as well as through crop residue effects on soil temperature and water content (Cox et al., 1990; Griffith et al., 1988; Imholte and Carter, 1987; Swan et al., 1990). However, yearly weather differences directly affect corn growth and yield, and also affect yield response to changes in soil 
properties created by tillage (Vyn and Raimbault, 1993; Dick et al., 1991). Thus long-term experiments comparing alternative tillage systems are required to evaluate their effects on corn yield under the variable temperature and rainfall conditions of the Corn Belt. Most long-term continuous tillage comparisons were located in the U.S. eastern Corn Belt and ontario, Canada (Dick et al., 1991; Dick and Van Doren, 1985; Griffith et al., 1988; Ismail et al., 1994; Vyn and Raimbault, 1993).

In a 20 year study in Ohio, Dick and Van Doren (1985) found that no-tillage (NT) had lower corn grain yields than moldboard plow (MP) on poorly drained silty clay loam soil but the reverse was true on low organic matter well drained silt loam soil. In an 18 year tillage study in Ohio, Dick et al. (1991) found that the relative performance of NT improved with time compared to MP on both well and poorly drained soils. Griffith et al. (1988) similarly found a relative yield advantage with time for NT compared to MP on low organic matter soil and attributed this to improved soil physical properties with NT. In contrast cox et al. (1990) found increased soil strength under continuous NT which could decrease soil water uptake and corn growth under dry conditions. In ontario, Vyn and Raimbault (1993) found yields of NT compared to MP tended to increase for 7 years but then decreased. They also found increased bulk density and soil strength with NT compared with MP. Ismail et al. (1994) and Dick et al. (1991) both found increased organic matter and nutrient concentrations at the surface on long term NT compared to MP treatments.

While weather conditions are recognized as important factors, their contribution to variation in crop yields is difficult to quantify especially when bulked monthly or seasonal climatic data is compared. The use of complex crop growth models to assess the impact of differing factors on crop growth and yield is hampered by data input requirements. Thus analyses of variance procedures are commonly used to assess the importance of tillage factors in agronomic research in spite of difficulties in quantifying weather effects and uncertainty in underlying assumptions regarding whether yearly weather effects should be considered fixed or random. The need for more detailed analyses was recognized by Cochran (1939), who observed that an analysis of variance for experiments lasting many years "should be only a preliminary to a more detailed investigation of the effect of the season on the responses to treatments", and cited the research of Fisher at Rothamsted on the "influence of rainfall on yields" as examples of such investigations.

The pattern of yield differences among tillage systems over time may be modified by yearly weather fluctuations. Thus the distribution of yearly weather effects in long term studies must be considered in assessment of yield trends. Consideration of 
inferences that can be made from designed experiments (with or without randomization of treatments to experimental units each year) conducted over a number of years raises the difficult question, not addressed in this paper, of length of time required to adequately sample variations in weather. In our study weather was the dominant factor on yield and performance of tillage systems. The ten years in this study naturally fell into two distinct groups, stress or non-stress years, on the basis of estimated crop water budgets. We considered years within the two groups of years to be random effects.

Our objective was to evaluate long-term effects of alternative tillage systems on corn growth and yield with continuous corn grown on low organic matter silt loam soils.

\section{MATERIALS AND METHODS}

The effect of no-tillage (NT), chisel plow (CH), and moldboard plow (MP) treatments on crop residue cover, plant density, and yield was measured from 1981 through 1990 on Palsgrove and Rozetta silt loam (fine-silty, mixed mesic Typic Hapludalfs) soils at the Lancaster Agricultural Research Station, Lancaster, Wisconsin. Over the 10 years, total area residue cover averaged $62 \%$ for $\mathrm{NT}, 13 \%$ for $\mathrm{CH}$ and $2 \%$ for MP. The site was a $600-\mathrm{m}$ long and $25-\mathrm{m}$ wide, north-facing contour strip with 10 to $12 \%$ slope. Row direction was east-west. Experimental units for tillage treatments were 31 to $33-\mathrm{m}$ in length, about $25-\mathrm{m}$ in width, and contained one to two $6-\mathrm{m}$ residue treatment subplots not included in this study. Therefore, blocks were placed in sequence along the strip. A general gradient in soil depth and plant available water exists from east to west along the strip which can cause differences in water stress and consequently in corn growth and yield (Swan et al., 1987). Soil depth (determined as depth to red clay residuum) ranged from $0.6-\mathrm{m}$ (east end) to $>1.5-\mathrm{m}$ depth (west replicate). Average soil depth for replicates 1 to 4 was $0.7 \mathrm{~m}, 1.1 \mathrm{~m}, 1.1 \mathrm{~m}$, and $1.5 \mathrm{~m}$, respectively. Average soil depth was $1.0 \mathrm{~m}$ for MP, $0.9 \mathrm{~m}$ for $\mathrm{CH}$, and $0.8 \mathrm{~m}$ for NT. The relationship of soil depth to grain yield differed among years in which water stress was observed(Swan et al., 1987). Differences in soil depth were included in estimates of water stress.

Planting dates ranged from 26 April to 17 May (Table 1). Row width was $0.9 \mathrm{~m}$. Plots were not cultivated following planting. The hybrids grown had 100 to 105 day relative maturity rating except in 1988 and 1989 when a 95 to 100 day hybrid was used. Soil fertility, weeds, disease, and insects did not appear to limit corn growth or yield. Plant density was measured as number of harvested ears. Water stress was observed (Swan et al., 1990) during silking and tasseling stages in 1983, 1984, 1985, and 1988, years with extended periods of low rainfall (Table 1). 
Water stress was calculated as the difference between estimates of potential and actual transpiration using an equation developed by Staricka (1985). Estimates of water stress for individual treatments and plots included factors affecting soil water availability and use including soil depth and tillage related differences in residue cover, infiltration rate, and rate of crop development (Swan et al., 1990). Estimated water stress was weighted based on stage of phenologic development and summed for a growing season as weighted water stress (WWS).

The three tillage treatments were randomly allocated to experimental units according to a randomized complete block design. Comparisons among tillage systems, and their interactions with other factors, were accomplished using orthogonal comparisons. Treatments remained on the same plots throughout the 10-year period. Thus, yield (and other variables) could not be assumed to be uncorrelated over time and were considered to be repeated measurements. Years were classified as stress or non-stress years on the basis of observed water stress and yearly weather factors. The difference in mean yields between the first two years and last two years of the study were used to investigate cumulative effects of tillage treatments. Total variability among years was partitioned into variability among years within stress years $(1983,1984,1985$, and 1988) and within the remaining non-stress years. A combined analysis over years was completed to estimate average treatment effects and to test whether these effects were consistent over years.

\section{RESULTS AND DISCUSSION}

Grain yields: Yearly average grain yields ranged from $10.7 \mathrm{Mg}$ $\mathrm{ha}^{-1}$ in 1987 to $3.3 \mathrm{Mg} \mathrm{ha}^{-1}$ in 1988 (Table 1). The effects of yearly weather conditions on grain yield dominated grain yield differences due to tillage (Table 2A; Fig. 1). Yearly grain yields were less than the 10 -year average of $8.3 \mathrm{Mg}$ ha-1 in the four stress years with WWS $>3 \mathrm{~cm}$ (Fig. 2). Grain yields for these four years averaged 6.0 (s.e.=0.4) Mg ha-1 compared to 10.1 (s.e.=0.5) $\mathrm{Mg} \mathrm{ha}^{-1}$ for the six non-stress years with WWS $<3 \mathrm{~cm}$. There were no differences among tillage treatments in the final year suggesting no cumulative effects. Grain yields for the three tillage systems were significantly different in 1984 and 1988, both years with WWS $>8 \mathrm{~cm}$ (Table 1). In 1988, grain yields for both $\mathrm{CH}$ and NT were significantly greater than for MP (Table $2 \mathrm{~A})$. In 9 of the 10 years, grain yield of $\mathrm{CH}$ and $\mathrm{MP}$ were not significantly different (Table 3). Grain yields of NT were significantly less than tilled treatments in 1981 and 1984, but were significantly greater than tilled treatments in 1989. The C.V. averaged $5.7 \%$ in non-stress years $(3.6 \%$ to $8.6 \%$ ) and $9.1 \%$ in stress years ( $4.3 \%$ to $14.2 \%)$, partly due to yield reduction due to WS. 
For the 10-year period mean grain yields were significantly different among replicates (Table 4). Mean yields for replicates one to four were $7.99,8.42,8.67,8.76 \mathrm{Mg}^{\mathrm{ha}}{ }^{-1}$ respectively. The increase in yield from replicates one to four reflected the general increase in soil depth from replicates one to four. The increase in plot yields with soil depth occurred primarily during stress years, ranging from 1.8 to $2.6 \mathrm{Mg} \mathrm{ha}^{-1} \mathrm{~m}^{-1}$ in 1983, 1984, and 1985 .

Water stress was the dominant factor affecting grain yield for the 10-year period (Table 4). Ninety-two percent of the total variability (sum of squares) in the experiment was accounted for by variability among years, and 75\% of the variability associated with years was accounted for by variability between stress $(n=4)$ and non-stress years $(n=6)$. Differences among tillage systems were similar in stress and non-stress years (Table 4). Over the 10 years, differences among tillage systems averaged $<0.1 \mathrm{Mg} \mathrm{ha}^{-1}$ and were not significant. Variability in yield was greater in stress years than in non-stress years, corresponding to greater range in yields among stress than non-stress years. During nonstress years the range in yearly grain yields was greatest for NT and least for MP, but the order was reversed for stress years (Tables 4 \& 5). The Til x Year/WS interaction may also be associated with significant differences in grain yield among tillage treatments in two of the four stress years (1984 and 1988) contrasted with no significant differences in non-stress years. For the years 1989-1990, compared with 1981-1982, grain yield increased $1.25 \mathrm{Mg} \mathrm{ha}^{-1}$ for $\mathrm{NT}$ but decreased $-0.12 \mathrm{Mg} \mathrm{ha}^{-1}$ for $\mathrm{CH}$ and MP (Table 6).

Grain yield was less than $8.4 \mathrm{Mg} \mathrm{ha}^{-1}$ when WWS $>8 \mathrm{~cm}$ (Fig 2). In non-stress years yields of individual tillage systems were 9.0 Mg ha-1 or greater, the WWS was $<3 \mathrm{~cm}$ and other factors such as plant density and GDD deficit affected grain yield more strongly than WWS (Swan et al., 1990). Average yearly grain yield of individual tillage treatments (YRLYLD) decreased nearly $0.3 \mathrm{Mg}$ $\mathrm{ha}^{-1}$ per $\mathrm{cm}$ WWS when WWS $>3 \mathrm{~cm}$ :

$$
\text { YRLYLD }=10.4 \mathrm{Mg} \mathrm{ha}-1-0.27 \text { (WWS) }
$$

with $\mathrm{R}^{2}=0.88, \mathrm{~S}_{\mathrm{yx}}=0.84 \mathrm{Mg} \mathrm{ha}^{-1}$, and $\mathrm{n}=12$. This equation agrees closely with that shown in Fig. 2 which include all years. Grain yield decreased as WWS increased for all tillage systems.

Plant density: Plant density (PD) differed significantly between tillage treatments in 5 years (Table 1). Greatest differences in PD among tillage systems were in stress years except for 1981 where differences were likely due to differences in planter depth adjustment on tilled and NT plots (Table 2B). In 1983 and 1988 , PD on MP plots was $>8000$ plants ha-1 less than NT and 7000 and 3000 plants ha-1 less respectively than $\mathrm{CH}$, 
indicating a greater decline in ear numbers for $\mathrm{MP}$ than for $\mathrm{CH}$ and NT under conditions of severe WS. Plant density on tilled treatments was greater than on NT in 1981 and 1985 but the reverse was true for 1983, 1986, 1987, and 1988 (Table 3). The average C.V. was similar for the six non-stress years (5.4\%) and the four stress years (4.8\%). For the years 1989-1990 compared with 1981-1982, average PD increased 17,800 plants $\mathrm{ha}^{-1}$ for NT compared with 12,400 plants $\mathrm{ha}^{-1}$ for $\mathrm{CH}$ and 11,100 plants ha ${ }^{-1}$ for MP (Table 6).

For the 10 years, mean PD differed less than 2000 plants ha-1 among tillage treatments and differences were not significant (Tables 2B \& 4). Differences in PD between replicates were significant for the 10 years. Mean PD for the 10-year period for replicates one to four were $63.9,63.5,62.8$, and 61.5 thousand plants ha-1. Plant density during non-stress years averaged 3800 (s.e.=2100) plants ha-1 greater than during stress years. The Til $x$ WS interaction was significant due mainly to the relative lower PD for MP compared to $\mathrm{CH}$ and NT in stress years and little difference (1000 plants $\mathrm{ha}^{-1}$ ) in non-stress years (Tables 4 \& 5). The variability (mean square) among years for non-stress years was greater than for stress years, which was associated with an increase of average PD during the study. During non-stress years, NT had both the greatest and lowest PD measured throughout the study (Table 2B). During stress years NT had the greatest PD and MP had the lowest. The range in PD during non-stress years was greater for NT $(26,600$ plants ha-1) than for tilled treatments $\left(15,400\right.$ plants $\left.\mathrm{ha}^{-1}\right)$. The range for NT(14,900 plants $\left.\mathrm{ha}^{-1}\right)$ and tilled treatments $\left(15,700\right.$ plants ha $\left.{ }^{-1}\right)$ was similar during stress years and was also similar to the range for tilled treatments during non-stress years (Table 4 \& 2B).

Relationship of differences in yearly grain yield between NT and tilled treatments to plant density: Since neither grain yields nor PD were significantly different between tilled treatments for the 10 years, the yearly difference between tilled and NT treatments for grain yields and PD were examined. Comparison of changes in yield and PD between beginning (19811982) and ending (1989-1990) years showed increased PD but no change in grain yield for tilled treatments (Table 6). Both PD and grain yield increased for NT. For non-stress years, mean yearly NT grain yield increased $0.06 \mathrm{Mg}(1000 \text { plants })^{-1}$ but the relationship of PD to mean yearly grain yield was not significant for $\mathrm{CH}$ and MP. The yearly differences in NT PD minus the average of MP and $\mathrm{CH}$ treatments ( $\Delta$ den 1000 plants $\mathrm{ha}^{-1}$ ) and the yearly difference in grain yield between NT and tilled treatments ( $\Delta$ yld $\mathrm{Mg} \mathrm{ha}^{-1}$ ) had similar trends with time (Fig. 3). The change in $\Delta$ den explained $51 \%$ of the variation in yearly grain yield between NT and tilled treatments (Fig. 4): 
$\Delta y I d=-0.03+0.095(\Delta$ den $)$

with $\mathrm{r}^{2}=0.51, \mathrm{~s}_{\mathrm{y}} \cdot \mathrm{x}=0.49 \mathrm{Mg} \mathrm{ha}^{-1}, \mathrm{n}=10$, and $\mathrm{p}<0.05$.

\section{SUMMARY AND CONCLUSIONS}

The effect of yearly weather conditions, in particular those related to water stress near anthesis, dominated other factors affecting grain yield. Differences between stress and non-stress years were significant at $\mathrm{p}<0.001$ for grain yield and PD. Grain yields were reduced on all treatments in stress years. Average yearly grain yield of tillage treatments decreased approximately $0.3 \mathrm{Mg} \mathrm{ha}{ }^{-1}$ per $\mathrm{cm}$ WWS for WWS $>8 \mathrm{~cm}$. In stress years, the increase in grain yield with soil depth ranged from 1.7 to $2.6 \mathrm{Mg}$ $\mathrm{ha}^{-1} \mathrm{~m}^{-1}$, and grain yield increased from replicates one to four in accordance with average soil depth of individual replicates. Differences among average effects of tillage treatments on grain yield were not detected for the 10-year period.

Mean plant density of tillage treatments differed in five years, but average tillage effects did not differ significantly for the 10 years. The MP treatment had greater decline in PD (ear number) during years with severe WS than did NT or $\mathrm{CH}$ treatments. The NT treatment had greater range in PD during nonstress years than MP or $\mathrm{CH}$, possibly due to increased variation in soil conditions and seed depth with NT when crop residue was present (Swan et al., 1994).

For non-stress years, grain yield increased as PD increased for NT but not for tilled treatments. Yearly differences in NT PD minus the average of tilled treatments explained over half the variation in yearly grain yield between NT and tilled treatments. The arrangement of years with and without water stress and the severity of water stress may also affect trends in relative yields among tillage systems. Yield differences among tillage treatments occurred only in water stress years of 1984, when MP yields were greater than NT yields, and 1988 when the reverse occurred. Based on results of Cox et al. (1991), tilled treatments may have had a relative yield advantage over NT in the first five years due to water stress in three of those years. Thus relative increase in NT grain yield with years may be explained to a large part by the particular pattern of yearly weather conditions encountered during the study and increases in PD of NT relative to tilled treatments. For these reasons and the contrasting results of tillage comparisons cited in the literature review, extension of the results of this experiment to other soil and weather conditions must be done with caution. 


\section{ACKNOWLEDGEMENTS}

Published as Iowa Agric. And Home Econ. Exp. Stn. Journal Paper No. J-17290. This research was supported in part by and conducted as part of North Central Regional Project NC-157, Integrated Crop, Soil and Animal Management systems for Upper Midwest Unglaciated Soils.

\section{REFERENCES}

Cochran, W.G. 1939. Long-Term agricultural experiments. J. Royal stat. Soc. Suppl. 2:104-149

Cox, W.J., R.W. Zobel, H.M. van Es, and D.J. Otis. 1990. Tillage effects on some soil physical and corn physiological characteristics. Agron. J. 82:806-812.

Dick, W.A., and D.M. Van Doren, Jr. 1985. Continuous tillage and rotation combinations effects on corn, soybean, and oat yields. Agron. J. 77:459-465.

Dick, W.A., E.L. McCoy, W.M. Edwards, and R. Lal. 1991. Continuous application of no-tillage to ohio soils. Agron. J. $83: 65-73$.

Griffith, D.R., E.J. Kladivko, J.V. Mannering, R.D. West, and S.D. Parsons. 1988. Long-term tillage and rotation effects on corn growth and yield on high and low organic matter, poorly drained soils. Agron. J. 80:599-605.

Imholte, A.A., and P.R. Carter, 1987. Planting date and tillage effects on corn following corn. Agron. J. 79:746 -751.

Ismail, I., R.L. Blevens, and W.W. Frye. 1994. Long-term no -tillage effects on soil properties and continuous corn yields. Soil Sci. Soc. Am. J. 58:193-198.

Staricka, J.A. 1985. Tillage-crop management models for corn production in southeast Minnesota. M.S. diss. University of Minnesota, st. Paul, MN

Swan, J.B., M.J. Shaffer, W.H. Paulson, and A.E. Peterson. 1987. Simulating the effects of soil depth and climatic factors on corn yield. Soil Sci. Soc. Am. J. 51:1025-1032.

Swan, J.B., J.A. Staricka, M.J. Shaffer, W.H. Paulson, and A.E. Peterson. 1990. Corn yield response to water stress, heat units, and management: Model development and calibration. Soil Sci. Soc. Am. J. 54:209-216.

Swan, J.B., R.L. Higgs, T.B. Bailey, N.C. Wollenhaupt, W.H. Paulson, and A.E. Peterson. 1994. Surface residue and in-row effects on long-term no-tillage continuous corn. Agron. J. $86: 711-718$.

Vyn, T.J., and B.A. Raimbault. 1993. Long-term effect of five tillage systems on corn response and soil structure. Agron $J$. $85: 1074-1079$. 
Table 1. YEARLY WEATHER AND MANAGEMENT FACTORS, AND MEAN PLANT DENSITY AND GRAIN YIELD (LEVELS OF SIGNIFICANCE CORRESPOND TO TESTS OF NO DIFFERENCE AMONG TILLAGE TREATMENTS) •

\begin{tabular}{|c|c|c|c|c|c|c|c|c|}
\hline \multirow[b]{2}{*}{ Year } & & & & \multicolumn{3}{|c|}{ Precipitation } & \multirow[b]{2}{*}{$\begin{array}{c}\text { Plant } \\
\text { Density }\end{array}$} & \multirow[b]{2}{*}{$\begin{array}{l}\text { Grain } \\
\text { Yield }\end{array}$} \\
\hline & \multicolumn{2}{|c|}{$\begin{array}{c}\text { Planting } \\
\text { Date }\end{array}$} & $\begin{array}{l}\text { Air } \\
\text { GDDI }\end{array}$ & $\begin{array}{l}1 \text { Apr. } \\
-31 \text { Oct. }\end{array}$ & $\begin{array}{l}50 \% \\
\text { Silk\# }\end{array}$ & $\begin{array}{l}\text { June } \\
\text {-Aug. }\end{array}$ & & \\
\hline & & & ${ }^{\circ} \mathrm{C}$ & & $\mathrm{mm}$ & & $1000 \mathrm{ha}^{-1}$ & Mg ha-1 \\
\hline 1981 & 6 & May & 1347 & 765 & 221 & 471 & $53.2 *$ & $10.1 \mathrm{~ns}$ \\
\hline 1982 & 17 & May & 1350 & 629 & 152 & 325 & $54.7 \mathrm{~ns}$ & $9.3 \mathrm{~ns}$ \\
\hline 1983 & 9 & May & 1559 & $607^{+}$ & 21 & 247 & $51.1 * *$ & $5.6 \mathrm{~ns}$ \\
\hline 1984 & 15 & May & 1263 & $744^{\mathrm{a}}$ & 96 & 360 & $64.0 \mathrm{~ns}$ & $7.2 *$ \\
\hline 1985 & 26 & Apr & 1336 & $596 \$$ & 106 & 172 & $63.3 *$ & $7.9 \mathrm{~ns}$ \\
\hline 1986 & 29 & Apr & 1371 & 631 & 81 & 279 & $71.9 \mathrm{~ns}$ & $10.2 \mathrm{~ns}$ \\
\hline 1987 & 30 & Apr & 1465 & 695 & 263 & 448 & $71.4 * *$ & $10.7 \mathrm{~ns}$ \\
\hline 1988 & 4 & May & $>1600$ & 315 & 99 & 131 & $64.2 *$ & $3.3 *$ \\
\hline 1989 & 27 & Apr & 1327 & 552 & 126 & 257 & $66.5 \mathrm{~ns}$ & $10.1 \mathrm{~ns}$ \\
\hline 1990 & $26 / 30$ & Apr & 1396 & 624 & 140 & 340 & $69.0 n s$ & $10.1 \mathrm{~ns}$ \\
\hline $10 \mathrm{yr}$ & avg. & & 1401 & 616 & 131 & 303 & $62.9 \mathrm{~ns}$ & $8.3 \mathrm{~ns}$ \\
\hline Long $t$ & rm av & & 1349 & 642 & & 329 & & \\
\hline
\end{tabular}

+ 1983, $29 \mathrm{~mm}$ precipitation 3 July to 25 August (53 d).

a $1984,39 \mathrm{~mm}$ precipitation 18 July to 31 August (45 d).

$\$ 1985,40 \mathrm{~mm}$ precipitation 28 May to 25 July (57 d).

I Air growing degree days planting to frost.

\# $50 \%$ silk date $-3 \mathrm{wk}$ to $+4 \mathrm{wk}$.

*, **, ns Significance at $0.05,0.01$, and nonsignificant at 0.05 level of probability, respectively.

Table 2A. CONTINUOUS CORN YIELDS. MEAN OVER FOUR REPLICATES

$$
\text { (Mg ha-1) }
$$

\begin{tabular}{lrrrrrrrrrrr}
\hline & \multicolumn{10}{c}{ Year } \\
\cline { 2 - 5 } Sys $^{101}$ & 82 & 83 & 84 & 85 & 86 & 87 & 88 & 89 & 90 & Mean \\
\hline NT & 9.49 & 8.99 & 5.34 & 6.75 & 7.52 & 10.37 & 11.13 & 3.69 & 10.75 & 10.22 & 8.43 \\
CH & 10.45 & 9.35 & 5.95 & 7.18 & 7.85 & 9.99 & 10.57 & 3.54 & 9.65 & 9.91 & 8.44 \\
MP & 10.51 & 9.64 & 5.54 & 7.60 & 8.36 & 10.27 & 10.55 & 2.71 & 9.76 & 10.16 & 8.51 \\
\hline LSD & 1.04 & 1.92 & 0.69 & 0.53 & 1.49 & 0.68 & 1.00 & 0.81 & 1.15 & 0.63 & 0.76 \\
\hline
\end{tabular}

$\$$ Sys=Tillage System; $\mathrm{NT}=\mathrm{No}-\mathrm{tillage} ; \mathrm{CH}=\mathrm{Ch}$ isel $\mathrm{Plow}$; MP=Moldboard Plow; LSD (0.05) 
Table 2B. CONTINUOUS CORN PLANT DENSITY. MEAN OVER FOUR REPLICATES (1000 Plants ha-1).

\begin{tabular}{lccccccccccc}
\hline & \multicolumn{10}{c}{ Year } \\
\cline { 2 - 11 } Sys & 81 & 82 & 83 & 84 & 85 & 86 & 87 & 88 & 89 & 90 & Mean \\
\hline NT & 47.5 & 52.7 & 54.1 & 62.2 & 59.5 & 73.2 & 74.1 & 69.0 & 67.2 & 68.5 & 62.8 \\
CH & 56.4 & 54.1 & 53.1 & 67.1 & 66.6 & 71.3 & 70.8 & 63.3 & 65.9 & 69.5 & 63.8 \\
MP & 56.0 & 57.4 & 46.0 & 62.6 & 63.9 & 71.1 & 69.3 & 60.2 & 66.5 & 69.1 & 62.2 \\
\hline LSD & 5.4 & 10.3 & 4.6 & 5.2 & 4.5 & 2.1 & 2.4 & 5.9 & 8.5 & 7.4 & 5.1 \\
\hline
\end{tabular}

$\$$ Sys=Tillage System; $\mathrm{NT}=$ No-tillage; $\mathrm{CH}=$ Chisel Plow;

MP=Moldboard Plow; LSD (0.05)

Table 3. TREATMENT COMPARISONS FOR GRAIN YIELD AND PLANT DENSITY FOR THE YEARS 1981-1990. (NT-TLD) IS A COMPARISON OF NO-TILLAGE (NT) VERSES TILLED (TLD) TREATMENTS. (CH-MP) IS A COMPARISON OF THE TWO TILLAGE TREATMENTS CHISEL (CH) AND MOLDBOARD PLOW (MP).

\begin{tabular}{|c|c|c|c|c|c|c|}
\hline \multirow[b]{2}{*}{ Year } & \multicolumn{3}{|c|}{ Grain Yield } & \multicolumn{3}{|c|}{ Plant Density } \\
\hline & (NT-TLD) & $(\mathrm{CH}-\mathrm{MP})$ & $C \cdot V$. & (NT-TLD) & $(\mathrm{CH}-\mathrm{MP})$ & $\mathrm{C} \cdot \mathrm{V}$ \\
\hline & $-----M g$ & $-1------$ & $\%$ & $--1000 \mathrm{Pl}$ & its $\mathrm{ha}^{-1}--$ & $\%$ \\
\hline 1981 & $-1 \cdot 0 *$ & $-0.1 n s$ & 5.9 & $-8.7 * *$ & $0.5 \mathrm{~ns}$ & 5.8 \\
\hline 1982 & $-0.5 n s$ & $-0.3 n s$ & 8.6 & $-3.1 \mathrm{~ns}$ & $-3 \cdot 3 n s$ & 9.5 \\
\hline 1983 & $-0.4 \mathrm{~ns}$ & $0.4 \mathrm{~ns}$ & 7.1 & $4.6 *$ & $7.0 * *$ & 5.2 \\
\hline 1984 & $-0.6 *$ & $-0.4 \mathrm{~ns}$ & 4.3 & $-2.6 n s$ & $4.5 \mathrm{~ns}$ & 4.7 \\
\hline 1985 & $-0.6 \mathrm{~ns}$ & $-0.5 \mathrm{~ns}$ & 10.9 & $-5.8 *$ & $2.8 \mathrm{~ns}$ & 4.1 \\
\hline 1986 & $0.2 \mathrm{~ns}$ & $-0.3 \mathrm{~ns}$ & 3.9 & $2.0 *$ & $0.1 \mathrm{~ns}$ & 1.7 \\
\hline 1987 & $0.6 \mathrm{~ns}$ & $0.0 \mathrm{~ns}$ & 5.4 & $4 \cdot 1 * *$ & $1.4 \mathrm{~ns}$ & 2.0 \\
\hline 1988 & $0.6 \mathrm{~ns}$ & $0.8 *$ & 14.2 & $7.3 *$ & $3.1 \mathrm{~ns}$ & 5.3 \\
\hline 1989 & $1.0 *$ & $-0.1 \mathrm{~ns}$ & 6.6 & $1.1 \mathrm{~ns}$ & $-0.6 n s$ & 7.4 \\
\hline 1990 & $0.2 \mathrm{~ns}$ & $-0.3 \mathrm{~ns}$ & 3.6 & $-0.8 \mathrm{~ns}$ & $0.4 \mathrm{~ns}$ & 6.2 \\
\hline
\end{tabular}

*,*, ns significant at 0.05 and 0.01 probability level and not significant, respectively. 
Table 4. SOURCES OF VARIATION, DEGREES OF FREEDOM, AND SUM OF SQUARES FOR GRAIN YIELD (Mg ha-1) AND PLANT DENSITY (1000 Plants ha-1)

\begin{tabular}{|c|c|c|c|c|c|}
\hline Source & $d f$ & Grain Yield & $\begin{array}{r}\text { Plant } \\
\text { Squares-- }\end{array}$ & Dens & $\begin{array}{l}\text { ity } \\
----\end{array}$ \\
\hline Replicate (Rep) & 3 & $3.6 *$ & 32.6 & * & \\
\hline Tillage (Til) & 2 & $0.1 \mathrm{~ns}$ & 26.2 & ns & \\
\hline Ea (Rep x Til) & 6 & 0.7 & 5.4 & & \\
\hline Water Stress (WS) & 1 & 482.5 & 428.1 & $* *$ & \\
\hline Til x WS & 2 & $0.6 \mathrm{~ns}$ & 60.7 & * & \\
\hline Eb (Rep x Til x WS) & 9 & 1.0 & 9.9 & & \\
\hline Years /WS & 8 & $20.2 * * *$ & 705.1 & $* * *$ & \\
\hline Stress Years & 3 & $49.6 * * *$ & & 490.3 & $* * *$ \\
\hline Non-stress Years & 5 & $2.5 * * *$ & & 833.9 & $* * *$ \\
\hline Til x Year/WS & 16 & $0.78 * *$ & 38.6 & $* *$ & \\
\hline Residual & 72 & 0.24 & 13.3 & & \\
\hline
\end{tabular}

Table 5. AVERAGE PLANT DENSITY AND RANGE IN YEARLY GRAIN YIELDS AMONG TILLAGE SYSTEMS FOR STRESS AND NON-STRESS YEARS •

\begin{tabular}{|c|c|c|c|c|}
\hline \multirow[b]{2}{*}{ Tillage\$ } & \multicolumn{2}{|c|}{ Range in Grain Yield } & \multicolumn{2}{|c|}{ Average Plant Density } \\
\hline & Stress & Jon-Stress & Stress & Non-Stress \\
\hline & $----\left(\operatorname{Mg~ha} a^{-1}\right)$ & ----- & $----(1000 \mathrm{Plants}$ & $\left.\mathrm{ha}^{-1}\right)-\cdots--$ \\
\hline NT & 3.8 & 1.8 & 61.2 & 63.9 \\
\hline $\mathrm{CH}$ & 4.3 & 1.2 & 62.5 & 64.7 \\
\hline MP & 5.7 & 0.9 & 58.2 & 64.9 \\
\hline
\end{tabular}

$\$_{\mathrm{NT}}=\mathrm{No}-\mathrm{Tillage} ; \mathrm{CH}=\mathrm{Ch}$ isel Plow; MP=Moldboard Plow

Table 6. Yield and plant density for initial an final years of study. Standard errors for comparison of average 1989-90 minus average 1981-82 were $0.14 \mathrm{Mg} \mathrm{ha}^{-1}$ for yield and 1050 plants ha ${ }^{-1}$ for plant density

\begin{tabular}{|c|c|c|c|c|c|c|}
\hline \multirow[b]{2}{*}{ Tillage } & \multicolumn{3}{|c|}{ Grain Yield } & \multicolumn{3}{|c|}{ Plant Density } \\
\hline & $1981-82$ & $1989-90$ & Change & $1981-82$ & $1989-90$ & Change \\
\hline & \multicolumn{3}{|c|}{$--------\mathrm{Mg} h \mathrm{ha}^{-1}--------$} & \multicolumn{3}{|c|}{---1000 plants $\mathrm{ha}^{-1}----$} \\
\hline NT & 9.24 & 10.49 & 1.25 & 50.1 & 67.9 & 17.8 \\
\hline $\mathrm{CH}$ & 9.90 & 9.78 & -0.12 & 55.3 & 67.7 & 12.4 \\
\hline MP & 10.08 & 9.96 & -0.12 & 56.7 & 67.8 & 11.1 \\
\hline
\end{tabular}


FIG. 1 YEARLY GRAIN YIELDS BY TILLAGE SYSTEM

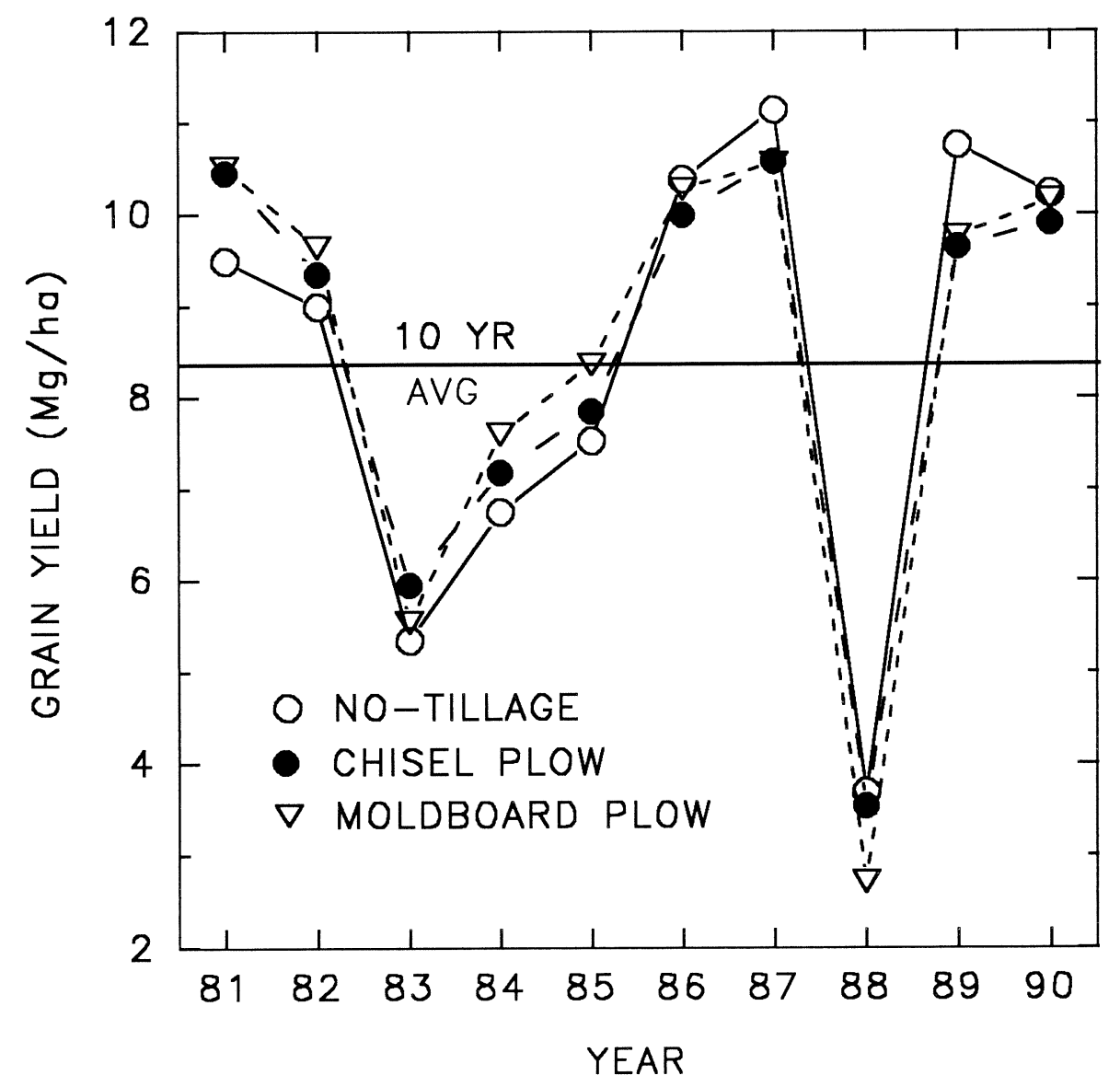




\section{FIG. 2 RELATIONSHIP OF YEARLY GRAIN YIELD TO WATER STRESS AND TILLAGE SYSTEM LANCASTER, WI, 1981-1990}

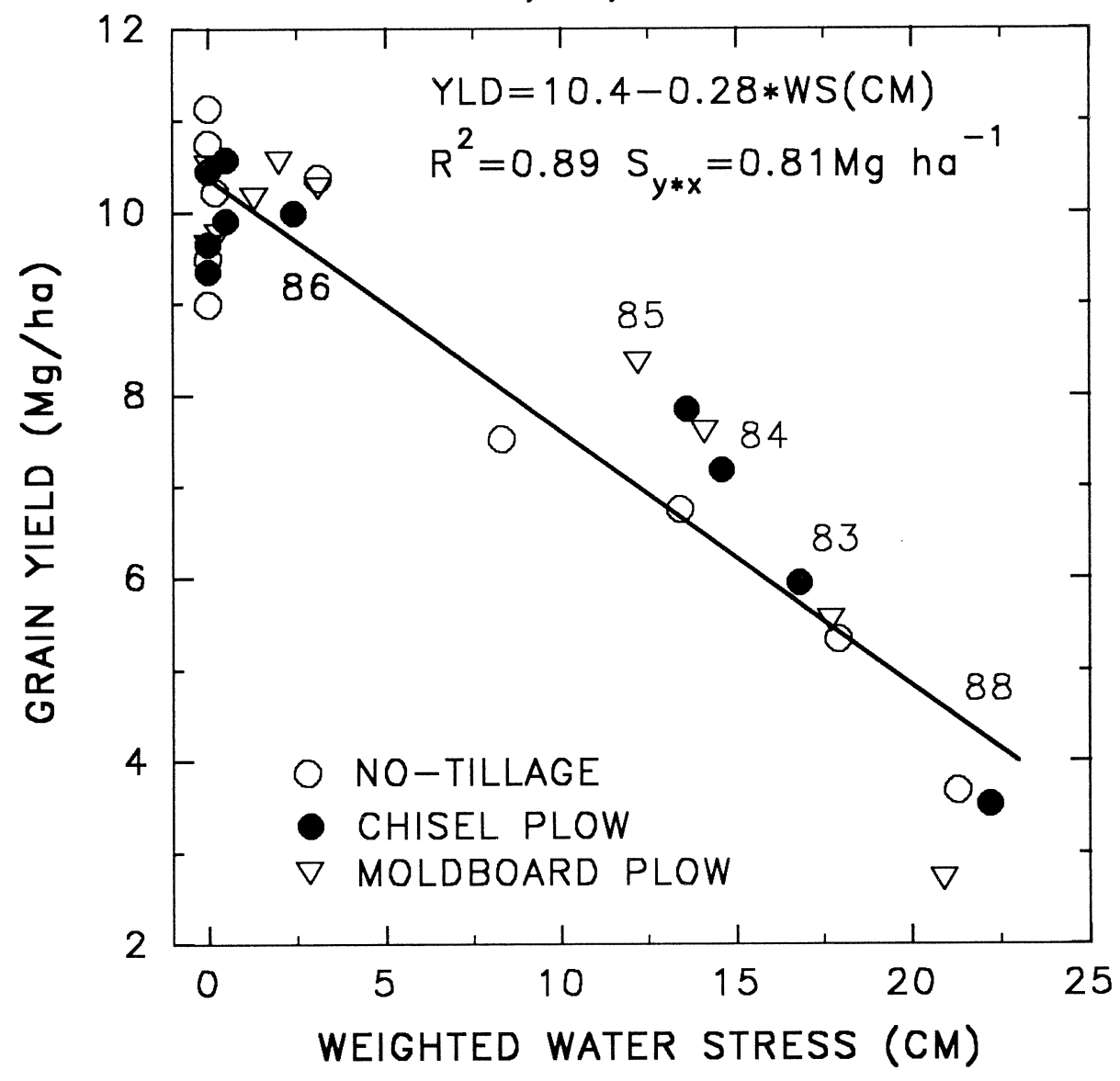


FIG. 3 DIFFERENCE IN PLANT DENSITY AND GRAIN YIELD BETWEEN NO-TILL AND TILLED TREATMENTS VS YEAR NUMBER

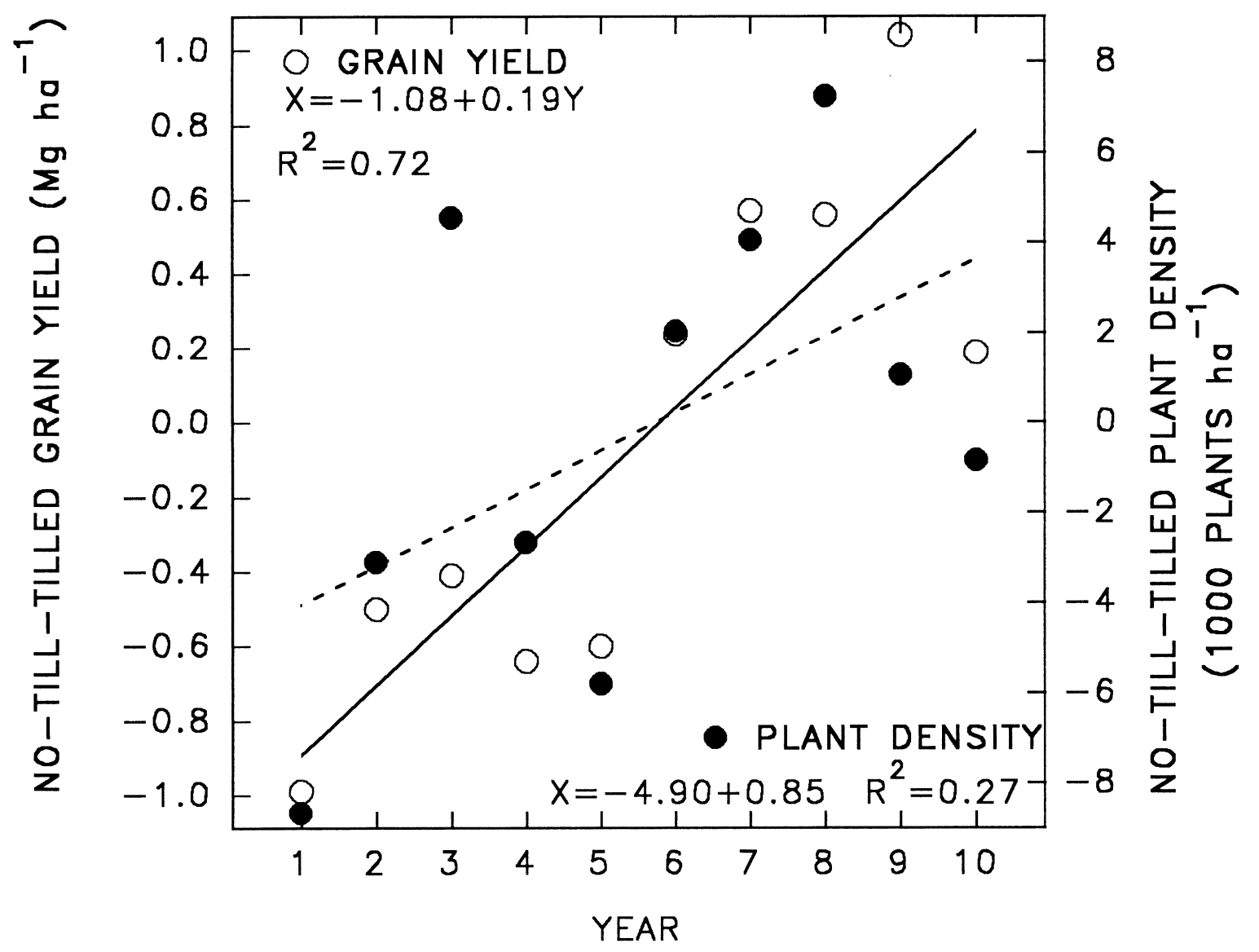


FIG. 4. RELATIONSHIP OF DIFFERENCE IN GRAIN YIELD BETWEEN NO-TILL AND TILLED TREATMENTS TO DIFFERENCE IN PLANT DENSITY

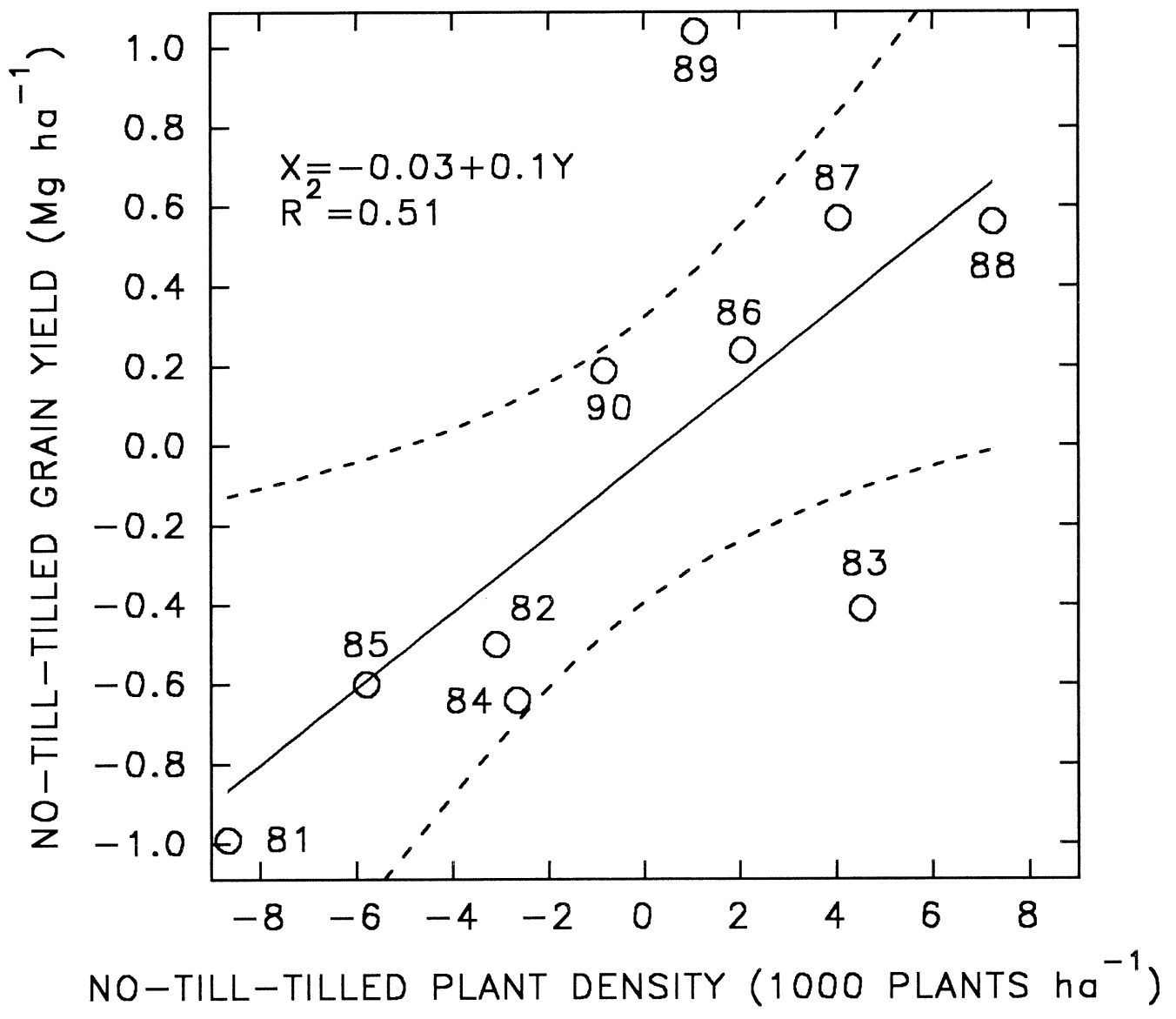

